\title{
Method for Analysis of Component Sugars by Fluorescence Labeling
}

\author{
ピリジルアミノ化による糖組成分析法 \\ Jun SUZUKI \\ Biotechnology Research Laboratories \\ Takara Shuzo Co., Ltd. Seta 3-4-1, Otsu, Shiga 520-21, JAPAN, FAX: 81-775-43-2494
}

Recently, various reports have appeared that stress the importance of the functions of sugar chains in the biological activity of complex carbohydrates. Techniques to study the structures of sugar chains have made great progress in the past decade, and many structures have been determined. The method for the fluorescence labeling of sugars with the use of 2-aminopyridine, first reported by Hase et al. (1) and further improved since, is one of the methods used for analysis. The chemical reaction of reductive pyridylamination is shown in Fig. 1. Takemoto et al. have used this method for the analysis
近年、複合梠質の生理活性を担う榶鎖構造の重要性につい て様々な報告がなされてきた。その研究のための榶鎖棈造解析 技術はこの十年間で非常に進歩し、数多くの榶鎖の構造が決定 されている。数ある榶鎖構造解析法の中で、2-アミノビリジ ンによる梼の蛍光標識法は長谷らにより開発され（1）、以 来、改良が重ねられてきた。榶のビリジルアミノ化（P A 化） 反応を図 1 に示す。武本らはこの方法を榶組成分析に応用し、

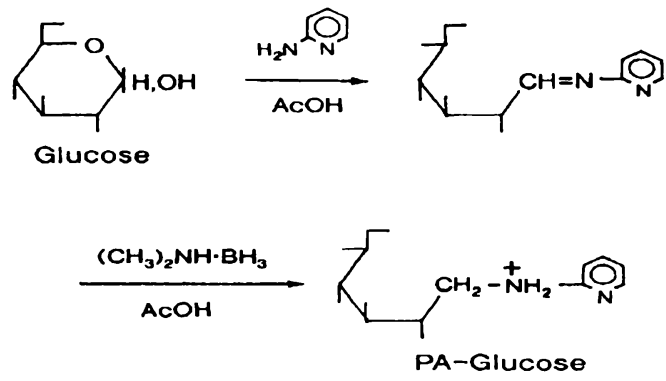

Fig. 1. Reductive Pyridylamination

of component sugars, and proposed a sensitive and simple method using high-performance liquid chromatography (HPLC)(2). Methods that use HPLC have become popular especially in the recent past, because the procedure is easy, the time needed for analysis is short, and the reproducibility is good. There are many other HPLC methods, including the radioactive detection of sugar alcohols labeled with tritium (3), and pulsed amperometric detection which does not require precolumn labeling because sugars have charges in alkaline conditions (4). Among the various methods, we expect the fluorescence labeling method to be the most sensitive. Recently we succeeded in simplifying the whole procedure, including the steps of hydrolysis, $\mathrm{N}$-acetylation, and pyridylamination (5). I would like to introduce our method here.

\section{Hydrolysis and $\mathbf{N}$-acetylation of a glycoconjugate}

Beforehand analysis, the glass tube to be used should be boiled in $4 \mathrm{~N}$ hydrochloric acid for $3 \mathrm{~h}$ and washed well with distilled water to remove the impurities derived from the glass that might interfere with the analysis. Next, to avoid the contaminants derived from dust in the air, especially glucose, the tube is heated in an airbath at $200^{\circ} \mathrm{C}$ for $3 \mathrm{~h}$. The sample $(100$ pmol - $10 \mathrm{nmol}$ ) is placed in the glass tube and freeze-dried. To
高感度でかつ簡便な分析法として、蛍光標識後 H P L Cにて分 析する方法を提唱した(2)。H P L Cによる分析法は最近特によ く使われるようになったがその理由として、操作が簡便であ り、分析時間が短く、再現性がよい、などが挙げられる。P A 化による蛍光検出法の他にも、トリチウム標識した糖アルコー ルを検出する方法 ( 3 )や榶を何ら標識せずアルカリ条件下で糖が チャージを持つことを利用した電気化学検出法 $(4)$ など、多くの 方法があるが、その中でも蛍光標識法がもっとも高感度な分析 法として期待される。最近我々は、複合榶質を酸加水分解、 $\mathrm{N}$ ーアセチル化した後、PA化する一連の反応の簡素化に成功し たので(5)、ここでその方法を紹介したい。

\section{1. 複合糖澌試料の酸加水分解、Nーアセチル化}

$100 \mathrm{pmol} \sim 10 \mathrm{nmol}$ の試料をガラス製試験管にとり、凍䊅 乾嬠などの方法で十分乾嬠させる。4 Mトリフルオ口酢酸50 $\mu 1$ を加えよく摫拌した後、減圧下封管する。（使用する試験管は ガラス由来のコンタミを取り除く意味で $4 \mathrm{~N}$ 塩酸中で 100 Cに て 3 時間加熟し、蒸留水でよくすすぎ、さらに空気中のほこり 
the residue is added $50 \mu \mathrm{l}$ of $4 \mathrm{M}$ trifluoroacetic acid, and the tube is sealed under reduced pressure. The tube is heated at $100^{\circ} \mathrm{C}$ for $3 \mathrm{~h}$ to hydrolyze the contents. After the tube is opened, ribose (100 pmol or $1 \mathrm{nmol}$ ) is added as an internal standard. The solution is dried under reduced pressure. Free amino groups are acetylated by the addition of $50 \mu \mathrm{l}$ of a mixture of pyridine, methanol, and water (3:6:2) plus $2 \mu$ of acetic anhydride. The solution is left at room temperature for $30 \mathrm{~min}$ with occasional stirring. Again the solution is dried under reduced pressure and a mixture of sugars is obtained.

\section{Pyridylamination of sugars by the PALSTATION}

Fluorescence labeling with the use of 2-aminopyridine can be done by the pyridylamination system PALSTATION (Takara Shuzo Co., Ltd., Kyoto, Japan). The residue obtained is dissolved in a small amount of water and transferred to a PALSTATION reaction vial. The solution is dried under a stream of nitrogen gas. After the addition of $10 \mu \mathrm{l}$ of a coupling reagent (prepared by $100 \mathrm{mg}$ of 2-aminopyridine being dissolved in $50 \mu \mathrm{l}$ of acetic acid and $60 \mu \mathrm{l}$ of methanol) to the residue, the solution is mixed well and heated at $90^{\circ} \mathrm{C}$ for $15 \mathrm{~min}$. Excess amounts of the reagents are removed by evaporation under a stream of nitrogen gas at $60^{\circ} \mathrm{C}$ for $20 \mathrm{~min}$. Then $10 \mu \mathrm{l}$ of a reducing reagent (prepared by $6 \mathrm{mg}$ of borane-dimethylamine complex being dissolved in $100 \mu \mathrm{l}$ of acetic acid) is added, and the solution is mixed well and heated at $90^{\circ} \mathrm{C}$ for $30 \mathrm{~min}$. The reaction mixture is dried under a stream of nitrogen gas with methanol and toluene to remove excesses of the reagents. Thus 2-aminopyridine is bound to the reducing end of the sugars, and fluorescent derivatives are made. Total recovery of sugars as pyridylamino (PA-) sugars is more than $90 \%$ for both neutral and $\mathrm{N}$-acetylamino sugars. The PA-sugars are stable against light, acid, and alkali, unlike many other fluorescent compounds. The PA-sugars obtained are dissolved in water, and a portion of the solution is injected directly into the HPLC apparatus. Assay is done by comparison of the peak heights of the PA-sugars of the sample to those of the mixture of standard sugars that was hydrolyzed, $\mathrm{N}$-acetylated, and pyridylaminated in the same way. Removal of excess reagents by evaporation under a stream of nitrogen gas with the use of PALSTATION is satisfactory; there is no need of purification after labeling, and the solution can be analyzed directly by HPLC. It would be difficult to inject the solution directly and to analyze the PAsugars if the excess reagents were not removed sufficiently. So when the PALSTATION is not used, it is necessary to gel-filter the sample after pyridylamination (2).

\section{HPLC analysis}

Separation of borate-complexes of sugars by anion-exchange chromatography is a classical method that has been studied for long. We have found that the borate-complexes of PA-sugars can be separated well by the use of a porous, quaternary amine-type resin. PALPAK Type A (Takara Shuzo Co., Ltd.), a strong-base anion-exchange column, can be used. The solvent is a mixture of 1 part of acetonitrile and 9 parts of $0.7 \mathrm{M}$
に含まれるグルコースなどのコンタミを取り除くためにエアバ スで 200 Cにに 3 時間加熱したものを用いる。）これを 100 C にて 3 時間加熱し酸加水分解を行う。開管し、内部標準として リボース $100 \mathrm{pmol}$ 又は $1 \mathrm{nmol}$ を添加して減圧下浱縮乾固する。 残渣をピリジンーメタノールー水溶液（3:6:2）50 41 に溶解し た挠、無水酥酸 $2 \mu 1$ を加え、時々㨘䢁しながら室温にて30 分 放置し、Nーアセチル化反応を行う。再び減圧下浱縮乾固し、 単糖混合物を得る。

\section{PALSTATIONによる単榶混合物のP A化}

榶質P A 化装置、PALSTATION （宝酒造）を用いて2 アミノピリジンによる蛍光標識反応を行った。先の残渣を少量 の水に溶解し、PALSTATION 専用バイアルに移し、窒素気流 下、澴縮乾固する。残渣にカップリング試薬（2ーアミノピリ ジン $100 \mathrm{mg}$ を酷酸 $50 \mu 1$ 、メタノール $60 \mu 1$ に溶解して調製) $10 \mu 1$ を加え、よく擋挥し、 $90^{\circ} \mathrm{Cにて} 15$ 分反応させる。窒素気 流下、 $60^{\circ} \mathrm{C}$ にて 20 分㳻縮乾固し、過剩の試薬を除く。残渣に還 元試薬（ボランージメチルアミンコンプレックス $6 \mathrm{mg}$ を酢酸 $100 \mu 1$ に溶解して調製） $10 \mu 1$ を加え、よく擋䢁し、90にて 30 分反応させる。再び過㮃の試薬を除くためにメタノール、ト ルエンを加えて窒素気流下共沸操作を行う。これらの操作によ り糖の還元末端に 2 -アミノビリジンを結合させ、蛍光物質と する。中性桾、Nーアセチルアミノ桾共、反応収率は $90 \%$ 以上 である。またビリジルアミノ化した糖は他の蛍光物質と異な ク、光、酸、アルカリに対しても非常に安定である。後は残渣 を水に溶解し、溶液の一部を直接 H P L C に注入して分析す る。定量は、同様に酸加水分解、 $\mathrm{N}$ ーアセチル化、P A 化した 標準単糖混合物と試料のP A 化糖のビークの高さを比較して行 なう。このようにPALSTATIONを使って窒素気流下、涱縮乾固 することにより、非常に効率よく過剩の試楽の留去が行えるの で、PA化後精製することなくそのままHPLC分析することが可 能となった。過剩の試薬を十分に除去しなければ、直接HPLC に注入して分析することは困難であるのでPALSTATIONを使用 しない場合、PA化後にゲルろ過を行うなどの操作が必要となる (2)。

\section{H P L C分析}

榶とホウ酸との錯体を陰イオン交換クロマトグラフィーで 分離分析する方法は古くから研究されていたが、我々はビリジ ルアミノ化桾の木ウ酸錯体が多孔性第 4 級アンモニウム型樹脂 を用いると非常によい分離を示すことを見い出した。カラムは 強塩基性陰イオン交換カラムである PALPAK Type A （宝酒 造）を用いた。溶出液は $0.7 \mathrm{M}$ ホウ酸緩街液（水酸化カリウム にて $\mathrm{pH} 9$ に調整）に $10 \%$ となるようアセトニトリルを混合し 
borate buffer adjusted to $\mathrm{pH} 9$ with potassium hydroxide. The flow rate is $0.3 \mathrm{ml} / \mathrm{min}$ and the column temperature is $65^{\circ} \mathrm{C}$. The excitation wavelength is $310 \mathrm{~nm}$ and the emission wavelength is $380 \mathrm{~nm}$. The separation of ten kinds of sugars, that are usually found in glycoconjugates, is shown in Fig. 2. Other
たものを $65^{\circ}$ にて $0.3 \mathrm{ml} / \mathrm{min}$ で流す。蛍光検出は励起波長 310 $\mathrm{nm}$ 、蛍光波長 $380 \mathrm{~nm}$ で行う。複合榶質によく見られる 10 種 類の糖の分離を図 2 に示した。PALPAK Type Aと同じタイプの

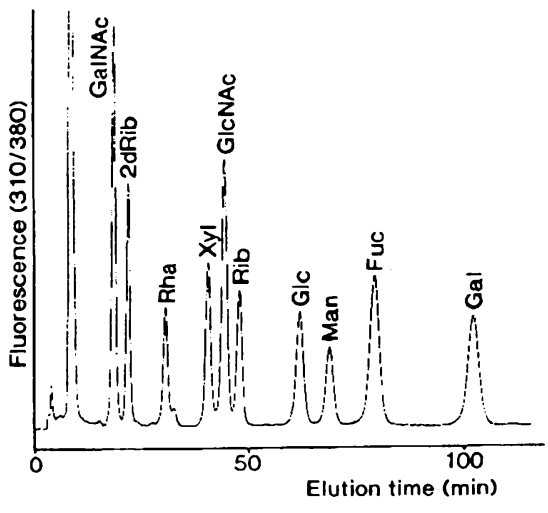

Fig. 2. Separation of Standard PA-sugars

columns of the same type as PALPAK Type A, such as TSKgel Sugar AXI (Tosoh Corp., Tokyo, Japan) and CarboPac PA-1 (Dionex Corp., Sunnyvale, CA, USA), gave good separation when borate buffer is used, although the conditions appropriate for each column are different. The amounts of PA-sugars were checked and standard curves of PA-sugars ranging from 10 pmol to $10 \mathrm{nmol}$ showed good linearity. The remaining trace of 2-aminopyridine and the protein and lipid parts of glycoconjugates were eluted in different regions from those of PA-sugars, so those impurities did not interfere with the component analysis of sugars. We have analyzed various glycoproteins and glycolipids with 100 pmol of the sample as the starting material, and confirmed that this method is useful.

Because this method is highly sensitive, even a trace amount of sugar can be detected. A question that always arises is whether the trace detected (especially when it is glucose) is one of the components of the sugar chain structure or not. This question depends very much on the degree of the purification of the sample. Conclusion cannot be made from component sugar analysis alone; other studies of the sugar chain structure are needed. However, to study the structure of an unknown sugar chain, it is usual to analyze the component sugars first. If this method of analysis is then used, the results will provide very useful information about the structure. We hope that this method will be of use to researchers studying sugar chain structures, and that studies of the structures and functions of glycoconjugates will be encouraged.

I thank Dr. Sumihiro Hase of Osaka University College of Science for his advice in the writing of this technical note.
カラム、例えば、TSKgel Sugar AXI（東ソー） PCarboPac PA1(Dionex) も溶出条件は異なるが、ホウ酸綏衝液を用いることに より同様に良い分離を得た。定量性に関しては、出発の糖の量 が $10 \mathrm{pmol}$ から $10 \mathrm{nmol}$ までの検量線を作成し、よい直線性を 示すことを確認している。また、残存する 2 ーアミノビリジン や試料のタンバク質、脂質部分由来のピークは早い時間に溶出 され、糖のピークと溶出位置が異なるので、桾組成分析には影 響しない。我々は様々な楉タンパク質、榶脂質試料を用いて出 発量 $100 \mathrm{pmol}$ の高感度分析を行ない、この方法の有用性を確認 している。

ここで常に問題となるのは、高感度分析であるがために、 わずかに検出される糖（特にグルコース）が糖鎖構造中に含ま れるものか否か、ということである。これは試料の精製度合に 大きく左右されるので、糖組成分析の䊅果だけから耛論が出世 るものではなく、他の糖鎖構造解析の䊅果も合わせて決定しな ければならない。しかし、未知の糖鎖の構造解析を行うにあた り、最初に糖組成分析を行うのは常套手段であり、その時にこ のような簡便で高感度な検出法を用いれば大变有益なデータが 得られることはまちがいない。本法が様々な糖鎖の構造解析を 行う一助となり、榶の構造と機能に関する研究が益々発展する ことを願っている。

本稿執筆にあたり適切なご助言をいただきました大阪大学 理学部の長谷純宏先生に感謝致します。

\section{References}

1. Hase, S., Ikenaka, T., and Matsushima, Y. (1978) Biochem. Biophys. Res. Commun. 85, 257-263

2. Takemoto, H., Hase, S., and Ikenaka, T. (1985) Anal. Biochem. 145, 245-250

3. Takeuchi, M., Takasaki, S., Inoue, N., and Kobata, A. (1987) J. Chromatogr. 400, 207-213

4. Hardy, M. R., Townsend, R. R., and Lee, Y. C. (1988) Anal. Biochem. 170, 54-62

5. Suzuki, J., Kondo, A., Kato, I., Hase, S., and Ikenaka, T. (1990) Agric. Biol. Chem., in press. 